\title{
EDUCATION AND TRAINING OF THE CHEMIST
}

$\mathrm{A}^{\mathrm{c}}$ CONFERENCE attended by about 250 chemists which was called by the Royal Institute of Chemistry to consider "The Education and Training of the Chemist" was held in the William Beveridge Hall, the Senate House, University of London, on the afternoon and evening of October 26. The president of the Institute, Dr. D. W. Kent-Jones, welcomed the company, especially the many visitors representing a great variety of educational and technical organizations and employing bodies. $\mathrm{H}_{\mathrm{o}}$ expressed his pleasure that Sir Ian Heilbron, who had much experience of the subject for discussion, had been able to accept the Council's invitation to preside at the opening session. Another distinguished chemist, Prof. J. W. Cook, took the chair for the evening session.

Sir Ian Heilbron said that the conference was timely in view of the national demand for an increase in the annual output of scientists. He stressed the need for avoiding the "relentless creation of a nation of specialists".

The five invited speakers, Dr. Norman Booth (industry), Sir Owen Wansbrough-Jones (government service), Prof. E. G. Cox (universities), Dr. E. G. Edwards (technical colleges), and Sir Eric James (schools), briefly presented their opening papers. These contributions have been published in full in the September issue of the Journal of the Institute. They covered a wide field and the discussion ranged over it. Difference in outlook mainly between the industrial and university representatives was manifest ; the opinions of the industrial group were not always urbanely expressed.

There were a number of criticisms of the university efforts. It was suggested that academic staffs were recruited for their research rather than for their teaching abilities so that their interests lay mainly with the few brilliant "alpha men", who would eventually teach in a university. The good "solid beta man" destined for industry got rather stepmotherly treatment.

The normal honours course found little favour. It was said that it put a premium on the ability to carry abstract concepts in the mind for a prolonged period with little contact with their application. One speaker called for its disembowelment, and its present high content of odd and unimportant facts replaced by a logical sequence of fundamental principles which the student should be trained to use in his thinking. The lecture system was criticized and voluminous note-taking at high speed deprecated.

But if the course was bad, the product was worse. Industry definitely does not want the brilliant highly trained specialist, who has come to the much-talkedof frontiers of knowledge, passed through the sensebarrier, and toppled into the abyss beyond. Brilliant scholars with breadth of knowledge are often extremely diffieult in a works. Intellectual cream concentrated in one place tends to turn sour. Men with a sound grounding in chemical principles who have been trained to think are required in large numbers. The conference was also told that there is more than a small gap, there is a howling wilderness between the product of a university and the require- ments of industry. Many fresh graduates coming out of universities looked and no doubt felt like fish out of water when they entered a factory ; they were unable to tackle the simplest matter without detailed instructions.

Experience in government departments differed radically from that in industry. The State authorities were in the main satisfied with the graduates they recruited and with the training these had received. The university grading was generally confirmed.

The industrial representatives placed great stress on the principle that the foreman should be able to knock out any man of his gang. One university product mildly but rashly suggested that, admitting the importance of practical training, it was perhaps a waste of time to teach a student to carry out analytical work with an accuracy approaching that of a routine analyst. He thought that a chemist in charge of technicians need not be able to carry out each of the operations he supervised better than the expert "a man who drives fat oxen need not himself be fat". This tentative view was regarded as "nonsense" and "a shocking thought". Indeed it was considered that university students and examiners attach too little importance to practical examinations when they exist. The young alpha graduate entering industry is somewhat delta when given a job at the bench.

The proposal that with the growth of fundamental knowledge it would eventually be necessary to add a year to the honours course found little favour. There was, however, a ready market for a suggestion which involved the replacement of the present final year by one in which the student was shown how practical problems are tackled and given practice in tackling them. Some considered that the training of a chemist should include an introduction to such subjects as applied electricity, fluid flow, unit operations of chemical engineering, and fuel technology.

On the academic side it was stressed that the universities would not entertain any considerable alteration in the type of work they were doing despite considerable pressure from without. All present were agreed that a chemist should be educated so that he would be a life-long student, who, apart from his training, would have acquired habits of study and be able to teach himself. The differences in opinion manifested in the conference were in relation to training rather than to education. The academicians held that practical skill was not sufficient to justify admission to the profession of chemistry-intellectual capacity must be the criterion for the award of honours. In this connexion the possibility was canvassed that some of the difficulties of industrialists with chemistry graduates arose from a tendency to employ chemists on routine practical operations proper to technicians.

It was admitted, however, that the university course could be streamlined so as to avoid overlapping and repetition. There was at times too great an emphasis on factual knowledge, for example, in the study of natural products and certain sections of inorganic chemistry. It was possible that there was undue concentration on research with lessened 
interest in teaching in modern departments of chemistry.

The proposal to have a final 'applied' year for an honours degree was rejected by the university representatives. They pointed out that students should study a full applied or a full academic course. Doubt was expressed about the intellectual content of the proposed applied year. A man taking it would be committed to applied chemistry as a career and would lose the freedom of choice that an honours graduate now received from his all-round basic training in chemistry. Further, the normal final year is essential to round off the work of the previous years. The present course is not too long by comparison with continental practice or with that of twenty years ago when there was so much less ground to be covered.

For the rest, the conference discussed with rather less tension a number of topics of interest, among them the teaching of science in schools. The point was made that so far as possible modern knowledge should be fed back to school classes and an effort made to introduce electronic theory at an early stage. Generally the lack of trained laboratory technicians was a stumbling block alike to the efficient presentation of chemistry and to the recruitment of teachers. Otherwise there was an optimistic note about science teaching in boys' schools. The position in girls' schools left more to be desired. Stress was laid on the possibility of increasing the supply of chemists by a wider recruitment of women. However, it was mentioned that their susceptibility to matrimony involves their frequent untimely removal from the profession.

Mathematics and physics were regarded as firstchoice ancillary subjects for the chemistry degree. But most of all the necessity for a thorough grounding in the English language was stressed. Precision and clarity so essential in discussing science depend on skill in manipulating language. The ability to think is largely dependent on the ability to use language. It was not thought that with the present over. loading of the courses in chemistry the student could find much time for the study of cultural subjects. These must be left to his home and school environment.

The importance of technical colleges in training a large number of students who otherwise would have no opportunity of receiving professional qualifications in chemistry was recognized. There was support for the view that it is wasteful for a young student of ability to have to undertake a chemical education solely through evening classes. Transfer to full-time or sandwich courses was recornmended. It appeared, however, that it is often more awkward for chemical than for engineering firms to fit in with sandwich courses. The difficulties of students from technical colleges who frequently have to sit externally assessed examinations, such as those of the Royal Institute of Chemistry, with no published syllabus was mentioned. Both teachers and students should have a reasonably precise statement of the course to be covered and should not have to depend on previous papers.

To return to the main issue, the impression gained was that some industrialists resemble patients, who could not care less whether their doctor has studied the premedical and preclinical sciences, if he can treat the common diseases and recognize an acute state needing hospitalization. Similarly, the employers require their chemists to have merely the theoretical knowledge and practical skill adequate to the duties assigned. It matters little if a professional chemical employee cannot recognize a lone pair of electrons if he sees one, or thinks an axial bond relates to pre-war diplomacy-provided his duties do not require a knowledge of these concepts. In this respect the industrialists follow the great Locke, who wrote in 1693 : "Could it be believed . . that a child should be forced to learn the rudiments of a language, which he is never to use in the course of life that he is designed to, and neglect all the while the writing of a good hand, and casting of accounts". The universities, of course, hold with Newman that science should be studied as a discipline and that general culture of the mind is the best aid to professional and scientific study. They reject the criterion that utility should be the basis of what is taught. They do not seek to train students to be professional practitioners, but rather to educate them so that eventually they become professional men of full stature. How to continue to accomplish these aims and also to modify the courses to satisfy the employers, if indeed this is desirable, remains for the future to solve.

T. S. WhEeler

\section{PHYSICS OF LIQUID HELIUM}

$\mathrm{O}$ RAL discussion between scientists who are unable to visit each other easily is commonly brought about by means of large-scale conferences. In the case of low-temperature physics, for example, international conferences are held at two-yearly intervals. They are attended by perhaps two hundred and fifty people and usually cover about eight more or less separate subjects. 'I'he high cost of travel to foreign countries, and the limited size of the conferences compared with the number of people actually engaged in the work, make it difficult or impossible for a young research worker to attend these meetings except when they take place in his own country. Moreover, when he is able to attend, he finds the atmosphere generally formal and indeed on occasion somewhat competitive, and the amount of time available for discussion is in any event strictly limited.

The Low Temperature Committee of the Physical Society, under the chairmanship of Dr. K. Mendelssohn, therefore considered that there is a place for occasional smaller meetings, in which it would be possible for young research workers as well as others directly interested to discuss informally the subject of their research. In order to provide for this, a series of one-day discussion meetings has been initiated, the first of which, on the subject of liquid helium, was held on November 2 at the Institute of Physics, and attended by about forty people. While it was not intended that the meeting should be an international one, it was thought that the discussion would benefit from a report on recent work in Leyden, and an invitation was sent to one research worker from the Kamerlingh Onnes Laboratory. The principal aim of the meeting was to allow adequate time for discussion of the work : the contributors were therefore asked to restrict the length of their papers to about ten minutes, and a rather longer time than this was allowed for discussion of each paper.

With a meeting of this kind, which is intended to be informal, it is neither possible nor desirable to make a full record of the individual contributions to the discussion. In the following report I have therefore summarized as completely as space allows 